\title{
THE FIRST RECORD OF HELOBDELLA NUDA (HIRUDINIDA, GLOSSIPHONIIDAE) IN LAKE BAIKAL
}

\author{
I. A. Kaygorodova ${ }^{1}$, S. Yu. Utevsky ${ }^{2}$ \\ ${ }^{1}$ Limnological Institute, Siberian Branch of Russian Academy of Sciences, \\ Ulan-Batorskaya, 3, Irkutsk, 664033 Russia \\ E-mail: irina@lin.irk.ru \\ ${ }^{2}$ V. N. Karazin Kharkiv National University, pl. Svobody, 4, \\ Kharkiv, 61022 Ukraine \\ E-mail: sutevsk@univer.kharkov.ua
}

Received 6 February 2012

Accepted 14 September 2012

The First Record of Helobdella nuda (Hirudinida, Glossiphoniidae) in Lake Baikal. Kaygorodova I. A., Utevsky S. Yu. - By far, the leech species Helobdella nuda (Moore, 1924) was known from China and the Amur River basin. It is found to occur in shallow waters of Lake Baikal.

Key words: Lake Baikal, leeches, Glossiphoniidae, Helobdella nuda.

Первая находка Helobdella nuda (Hirudinida, Glossiphoniidae) в озере Байкал. Кайгородова И. А, Утевский С. Ю. - До сих пор пиявка Helobdella nuda (Moore, 1924) была известна из Китая и бассейна Амура. Было обнаружено, что этот вид встречается на мелководье озера Байкал.

Ключевые слова: озеро Байкал, пиявки, Glossiphoniidae, Helobdella nuda

\section{Introduction}

The rhynchobdellid leech Helobdella nuda (Moore, 1924) is a poorly known species of the family Glossiphoniidae (Clitellata, Hirudinida). The species has been recorded from China (Suzhou, Nanking) and the Russian Amur basin (Khanka Lake, Udyl Lake, Kizi Lake, Bolonj Lake). According to C. F. Wu (1930) and Y. Chen (1962) this leech is common in the aforementioned localities of China. Moore (1930) supposed that in China $H$. nuda occupies the place of its widespread Palaearctic congener Helobdella stagnalis (Linnaeus, 1758).

E. I. Lukin (1960) found that both the species occurred in the lower reaches of the Amur. However, Helobdella stagnalis was less abundant there in comparison with its abundance in other areas of the Palaearctic region. Helobdella nuda, in turn, was rarer than in China.

Thus, according to the previous records, H. nuda could be assigned to elements of the China-Amur fauna, which once was widespread in the major portion of Asia. E. I. Lukin (1978) further speculated that later on, when environmental conditions were changed, this leech was superseded by widespread Palaearctic species in the north and Indo-Malayan species in the south. This research suggests that $H$. nuda occurs beyond the area where it has been recorded so far.

\section{Material and methods}

Leech specimens were collected by one of the authors, Dr. Irina Kaygorodova, during a field trip to the Chivyrkuy Bay of Lake Baikal at the end of August 2011. The specimens were photographed alive, fixed and preserved in $80 \%$ ethanol. Species definition was done using identification keys by E. I. Lukin (1976) and the original description (Moore, 1924).

\section{Results and discussion}

Two individuals were collected in coastal waters of the eastern part of the Zmeyovaya Bay (Chivyrkuy Bay, 53 $46^{\prime} \mathrm{N}, 109^{\circ} 02^{\prime} \mathrm{E}$ ). The leeches were found on the bottom surface of flat rocks at a depth of $0.7 \mathrm{~m}$. 


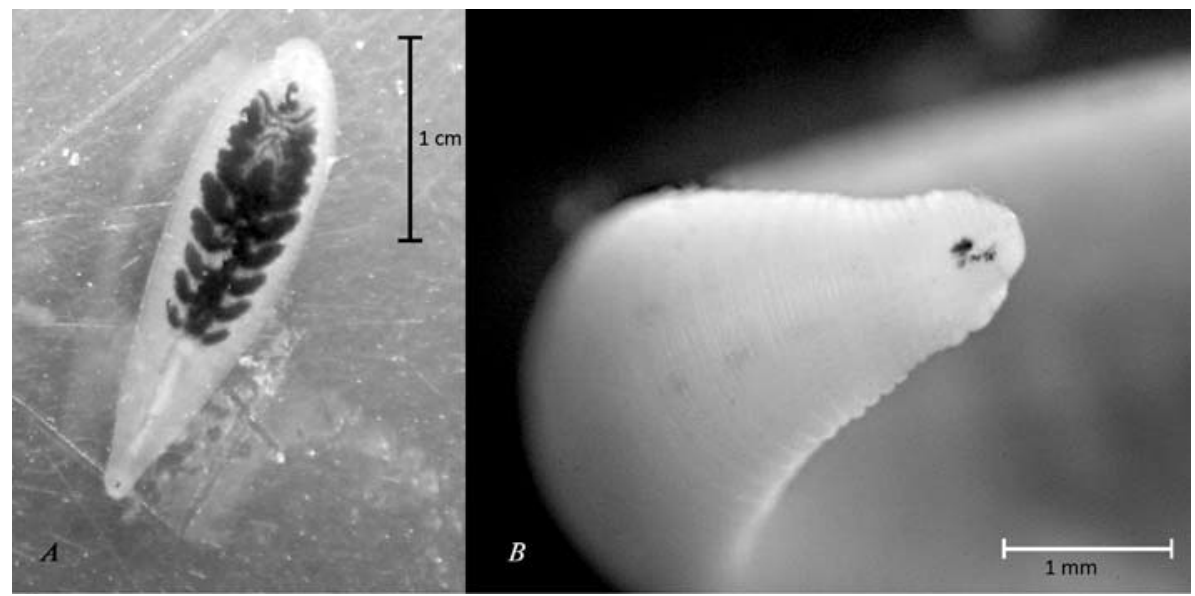

Fig. 1. Helobdella nuda from Lake Baikal: $A$, an individual with a conspicuous digestive system filled with host blood; $B$, the anterior end of the leech with eyes.

Рис. 1. Helobdella nuda из озера Байкал: $A-$ индивидуум с хорошо заметной пищеварительной системой, наполненной кровью хозяина; $B-$ передний конец пиявки с глазами.

The leeches are small in size, 5-8 $\mathrm{mm}$ at a moderate contraction. The body is smooth, with no tubercles. The pigmentation is weakly developed. Eyes are more than one pair in contrast to $H$. stagnalis (fig. 1). Gonopores are separated by one annulus. The digestive system can be easily seen through the skin. There are six crop caeca with the long posterior pair. Probably, the anterior pair is reduced or vestigial. Therefore, the number of caeca is less than seven as in the original description by J. P. Moore (1924). However, the variability of this character has been already recorded by E. I. Lukin (1976). The life style seems to be similar to that in the congener species. As H. stagnalis, it cannot swim and feeds on the haemolymph of freshwater invertebrates.

Our new record of $H$. nuda suggests that the range of this species is much wider than considered before and is not restricted to the Sino-Japanese region.

The study was supported by the Russian Foundation for Basic Research (grant No. 11-04-90452_Ukr) and the Ukrainian State Fund for Fundamental Research (grant N. Ф40.4/068).

Chen $Y$. An account of the leeches found in Nanking and vicinity with description of new species Placobdella sinensis // Acta Acad. Bras. Sci. Rio. - 1962. - 9. - P. 13-26.

Lukin E. I. Elements of the leech fauna of China and Japan in the fauna of the Amur River within the USSR // Zoologichesky zhurnal. - 1960. - 39, N 1. - P. 40-44. - Russian : Элементы фауны пиявок Китая и Японии в фауне реки Амур в пределах СССР.

Lukin E. I. Leeches of fresh and brackish waters (Fauna of the USSR; Vol. 1 : Leeches). - Leningrad : Nauka, 1976. - 484 p. - Russian : Пиявки пресных и солоноватых водоёмов (Фауна СССР; Т. 1 : Пиявки ).

Moore J. P. Notes on some Asiatic leeches (Hirudinea) principally from China, Kashmir, and British India // Proc. Acad. Sci. Philadelphia. - 1924. - 76. - P. 343-388.

Moore J. P. Leeches (Hirudinea) from China with description of new species // Proc. Acad. Sci. Philadelphia. - 1930. - 82. - P. 169-192.

Wu C. F. A revised list of the Chinese leeches // Bull. Dep. Biol. Yenching Univ. - 1930. - 1 (2). P. 45-48. 